\title{
Původ, význam a používání přezdívek u bulharských Čechů
}

\author{
Lenka J. Budilová \\ Katedra antropologických a historických věd Fakulty filozofické Západočeské univerzity v Plzni, \\ Sedláčkova 15, 30614 Plzeř
}

Do redakce doručeno 20. listopadu 2011; k publikaci přijato 14. února 2012

Text je dílčím výstupem projektu GAČR č. P405/10/0471

\section{THE ORIGINS, MEANING AND USE OF NICKNAMES IN CZECH VILLAGES IN BULGARIA}

\begin{abstract}
The article deals with naming practices among Czechs who lived in the first half of 20th century in two Bulgarian villages Vojvodovo and Belinci, and who left Bulgaria after WWII. The text analyzes the origins, the use and the meaning of nicknames in the studied population in 1900-1950. It draws on fieldwork carried out among the people who migrated from Bulgaria and settled in several towns and villages in South Moravia (region of Mikulov and Valtice) and their descendants. Naming practices of Bulgarian Czechs are analyzed in relation to naming strategies of Bulgarians. Nicknames are classified into several groups: patronymic nicknames, occupational nicknames and unique personal nicknames. The system of nicknames, which evolved as a third classificatory element to help organize the local social world, is studied in respect to strategies of giving, using and concealing nicknames in different contexts. Two sets of nicknames, used by the Czech and Bulgarian inhabitants of the village, respectively, are studied as an expression of the existence of two distinctive moral communities.
\end{abstract}

KEY WORDS Bulgarian Czechs; nicknames; names; naming practices; Vojvodovo; Belinci

\begin{abstract}
ABSTRAKT Př́spěvek se zabývá problematikou jmen a strategiemi pojmenovávání u bulharských Čechů, evangelíků, kteří žili v první polovině 20. století ve dvou bulharských obcích, Vojvodovo a Belinci. Vychází přitom z dat získaných během terénních šetření v několika obcích na Valticku a Mikulovsku, kde dnes žijí přesídlenci z Bulharska a jejich potomci. V textu jsou vedle rodných jmen a přímení analyzovány zejména přezdívky bulharských Čechů vzhledem $\mathrm{k}$ jejich původu, významu a způsobu užívání. Přezdívky, které se zde vyvinuly jako třetí klasifikační systém (vedle rodných jmen a příjmení), jsou klasifikovány do několika kategorií a je sledován jejich význam pro dané společenství. Text se zabývá také strategiemi dávání, užívání či zamlčování přezdívek v různých kontextech, a sleduje danou problematiku ve vztahu k systému pojmenovávání v rámci sociálního prostředí, které dané společenství obklopovalo (bulharské pravoslavné obyvatelstvo). Poukazuje pak také na skutečnost, že v rámci Vojvodova byly používány dva odlišné soubory přezdívek pro stejné osoby, což odráží existenci dvou rủzných morálních společenství v rámci jedné obce.
\end{abstract}

KLÍČOVÁ SLOVA Bulharští Češi; přezdívky; jména; pojmenovávání; Vojvodovo; Belinci

\section{ÚVOD}

Zkoumání jmen a pojmenování osob či věcí má v sociální antropologii dnes již poměrně bohatou tradici. Jména byla zkoumána nejčastěji jako součást symbolického výkladu světa, který dané společenství sdílí, nebo jako prvek klasifikačního systému používaného pro organizování sociálních vztahů. Dnes již klasickou je Lévi-Straussova teze o tom, že osobní jména mají ze strukturálního hlediska podvojný vý- znam: na jedné straně vypovídají o př́slušnosti pojmenovávaného jednotlivce $\mathrm{k}$ nějaké předem dané kategorii, a lze je tedy označit za cosi jako identifikační známku; na straně druhé jsou však zároveň svobodným výtvorem individua, které pojmenovává a vyjadřuje tak prostřednictvím pojmenovávaného aktuální stav vlastní subjektivity (Lévi-Strauss 1996, 222). Jména tak byla $v$ antropologii zkoumána nejčastěji jako instituce stojící na průsečíku dvou tendencí: na jedné straně individualizace, snahy vymezit jedinečnost člověka, a na stra- 
ně druhé tendence zařadit osobu do pletiva sociálních vztahů. Goodenough (1965) např́klad srovnává dvě společenství v Souostroví Karolíny (Truk) a v Bismarckově souostroví (Lakalai). V prvním případě je systém pojmenovávání velmi individualizovaný a má kompenzovat fakt, že jednotlivec je $\mathrm{v}$ této společnosti vnímán primárně jako člen své matrilinie a jeho osobnost je do značné míry potlačována. Ve druhém př́padě se zase setkáváme se složitým systémem teknonym a cyklů jmen, což má kompenzovat individualistické hodnoty této společnosti zdůrazňující úspěch a osobní schopnosti tím, že jména jedince začleňují do systému sociálních vazeb (Goodenough 1965, 271-275). Slavnou se stala také analýza používání a významu teknonym, tedy pojmenování osob prostřednictvím jmen jejich dětí, mezi neurozenými obyvateli Bali z pera manželů Geertzových, v níž ukazují, jak zde používání teknonym slouží jednak k třídění společnosti do jednotlivých věkových (generačních) tříd a jednak $\mathrm{k}$ vytváření velmi flexibilních korporovaných descendentních skupin, což umožňuje právě strukturální genealogická amnézie spojená s užíváním teknonym (Geertz - Geertz 1964).

Jména však v řadě společností jsou (či byla) považována nikoli jen za pouhá slova, etikety, arbitrární označení osob či věcí. Jménům se často přisuzuje význam přesahující pouhé označení, a tak se stávají sociálními entitami sama o sobě. Setkáváme se např́klad $\mathrm{s}$ vírou $\mathrm{v}$ magickou moc jména či s jejich tabuizací, tedy zákazem určitá jména (nebo za určitých okolností) vyslovovat (Goodenough 1965, 271; Barnes 1967, 112), případně s praxí výměny jmen mezi jednotlivci či celými rodinami (Rivers 1900, 77). Např́iklad zákaz vyslovování jména ještě nenarozeného dítěte, s nímž se setkáváme $\mathrm{v}$ některých tradičních společnostech, vychází z obavy o osud dítěte a předpokládá bytostnou jednotu mezi jménem a osobou, kterou označuje, a moc jména ovlivňovat jeho nositele co do osudu, zdraví či charakterových vlastností (Svoboda 1947, 105; pro Bulharsko srov. Krăsteva-Blagoeva 1999, 66). Pozornost byla věnována také vztahu pojmenovávání $\mathrm{k}$ ideologii daného společenství, k centrálním rituálům s ním souvisejícím (křest), vzniku „duchovního příbuzenstvi“ (kmotrovství) či slavení svátků oblíbených světců, jak na řeckém kontextu ukazuje např́klad Bialor (1967).

Způsoby pojmenovávání byly studovány také jako výraz vztahu mezi člověkem a místem. Nezřídka to totiž bývalo právě místo, co dávalo jméno člověku, a nikoli naopak. Lévi-Strauss (1996, 241) uvádí př́klad kalifornských Juroků, kteří odvozovali osobní jména lidí od bydliště či rodiště manžela nebo manželky, otce nebo matky: jméno tak zároveň vypovídalo jak o př́slušnosti $\mathrm{k}$ lokalitě, tak o situovanosti jednotlivce vzhledem k druhým (vdaná - ovdovělý, apod.). Významnou roli míst v pojmenovávání jednotlivců a rodin však máme doloženou také z evropských společností. Na skutečnost, že řada dnešních př́imení $\mathrm{v}$ německy mluvících zemích je odvozena ze jmen domů či hospodářství poukazuje například Dülmen (1999, 15). Zvyk užívání jmen „po domě“ dokládá též Pine u Góralů z Podhale v podhůří polských Tater (Pine 1996, 446). O podobném užití jmen domů pak máme doklady také z Bulharska, kde jméno bylo považováno za součást symbolické- ho bohatství domu, a proto bylo třeba jej neustále obnovovat a udržovat v domě (Krăsteva-Blagoeva 1999, 63). Používání jmen po domech či usedlostech je však doloženo také v českých zemích (Beneš 1962, 9-10; Moldanová 1983, 12).

Současné antropologické prŕístupy pak oproti klasickým textům kladou v souvislosti $s$ analýzou jmen a pojmenovávání důraz například na politický aspekt procesu pojmenovávání a moc, kterou obsahuje, na vztah mezi jménem a identitou člověka, či roli jmen nejen v (kolektivní) paměti, ale také v (kolektivním) zapomínání (pro přehled viz vom Bruck Bodenhorn 2006).

Způsoby pojmenovávání osob v česky mluvícím prostředí se zabývá bohatá literatura antroponomastická, která sleduje např́iklad utváření rodných jmen v češtině (Šmilauer 1974; Knappová 1989), tvorbu osobních jmen v nejstarším vývojovém období (Pleskalová 1998), původ a způsob utváření českých příjmení (Beneš 1962), či příjmení v současné češtině z vývojového i jazykovědného hlediska (Knappová 1992). $\mathrm{V}$ některých studiích je zohledňován také vztah pojmenovávání $\mathrm{k}$ lidovým představám a charakteru sociálních vztahů v nejstarších obdobích, kdy docházelo k tvorbě osobních jmen. Tak se například poukazuje na to, že také v evropském dávnověku nebývalo jméno pouze prostředkem k označování a rozlišování osob, ale bylo považováno za součást dotyčného, s nímž tvořilo jakousi magickou jednotu a určovalo tak jeho osud (Svoboda 1947, 101-102). Výběr rodného jména dítěte byl často motivován strachem o život dítěte, snahou ochránit jej před zlými silami, či touhou, aby se stalo nositelem žádoucích vlastností (Svoboda 1947). Přezdívky jsou pak klasifikovány jako dodatečné pojmenování, které člověk získává v průběhu života na základě nápadných tělesných či povahových vlastností či podle jiných okolností (Svoboda 1964, 41). Jsou to neúrérní vlastní jména, která charakterizují osoby např́íklad odkazem k povolání, vlastnostem či původu nositele, a mohou obsahovat pozitivní i negativní hodnocení (Pleskalová - Karlík - Nekula 2002, 354). Přezdívky jsou většinou analyzovány vzhledem ke způsobu jejich tvorby z hlediska jazykovědného, zároveň jsou však považovány také za svědky "dobové společenské situace i mezilidských vztahư" (Knappová $1999,88)$.

\section{BULHARŠTÍ ČEŠI}

Jako bulharské Čechy označuji společenství česky mluvících evangelíků, kteři žili v letech 1900-1950 jednak v obci Vojvodovo v severozápadním Bulharsku a od roku 1935 také ve vesnici Belinci v okrese Isperich na východě země. Vojvodovo, ležící 15 kilometrů jižně od dunajského přístavu Orjachovo, bylo založeno v roce 1900 zejména česky mluvícími evangelíky z vesnice Svatá Helena v Banátu (pro podrobnější popis peripetií stěhování ze Svaté Heleny do Bulharska srov. Jakoubek 2010a, 33-72). V obci žili kromě česky mluvících obyvatel také Slováci (srov. Botík 2005), pocházející z některých (dnes) srbských (Kovačica, Padina, Veliko Središte, Silbaš), mad’arských (Pitvaroš) a bulharských obcí (Gorna Mitropolja, 
Podem, Brašljanica) (srov. Michalko 1936, 69-77), a několik rodin bulharských.

Pro pochopení hodnotového systému a životního stylu bulharských Čechů je třeba zdůraznit jejich specifickou a ve společenství udržovanou religiozitu. Identita společenství, které zde označujeme jako bulharské Čechy, byla po dlouhou dobu identitou primárně náboženskou: traktovali se především jako „věřící, nikoli jako „Češi“'. Identifikace s českým (resp. československým) národem u nich $\mathrm{v}$ průběhu první poloviny 20. století musela být teprve budována, přičemž výraznou roli v tom sehrály aktivity orgánů československé krajanské péče zejména v oblasti školství (srov. Jakoubek 2010b). Po př́ichodu do Bulharska se evangelíci ze Svaté Heleny připojili k místní metodistické církvi (Michalko 1936, 244; Jakoubek 2010a, 83-85). Páteř́ jejich víry byl individuální vztah s Bohem, důraz na asketickou morálku (zŕíkali se nejen alkoholu, ale i tance, písní a jiných „světských radovánek“), a pojetí exkluzivní spásy. Jednota náboženské obce ve Vojvodovu byla později narušena a v roce 1925 spory vrcholí rozdělením metodistického sboru, kdy asi polovina jeho členů následuje nového kazatele G. Kowala a vymezuje se vůči metodistům. Nově odštěpená konfese odmítá křest dětí, aplikuje představu všeobecného kněžství, klade důraz na asketickou morálku, individuální vztah $\mathrm{s}$ Bohem a veřejné deklarování této víry (podrobněji k rozkolu viz Jakoubek 2010a, 90-95). Kowalovi následovníci se začali označovat a byli označováni jako darbisté. ${ }^{1}$ Vojvodovští Češi a jejich potomci o této události dodnes referují jako o „rozdělení kostelü“, protože tento rozkol se brzy manifestoval stavbou druhého kostela v horní ćásti obce (srov. Michalko 1936, 245; Nešpor - Hornofová - Jakoubek 2001, 75). Od té doby se obyvatelé obce dělí na ty, kteří navštěvují ",horní kostel“ (darbisté) a na ty, kteří chodí do kostela „dolního" (metodisté). Př́slušnost ke kostelu se předávala v rodinách, $\mathrm{v}$ prípadě smíšených sňatků pak platilo pravidlo, že žena má následovat svého muže. Vztah mezi oběma konfesně vymezenými tábory je našimi informátory popisován rozporuplně, od korektních vztahů až po vzájemnou nevraživost a ideál vzájemné endogamie obou kostelu.

Ve 20 . a 30. letech 20 . století dochází $\mathrm{k}$ dvěma vlnám migrace $\mathrm{z}$ Vojvodova, a to (zejména) $\mathrm{z}$ důvodu relativního přelidnění a nedostatku půdy $\mathrm{v}$ obci. $\mathrm{V}$ důsledku uplatňovaných dědických strategií se půda vojvodovských rodin v každé generaci dělila a výsledkem byla situace, kdy hospodársství už nedokázala uživit své majitele (srov. Budilová 2011). V roce 1928 tak odchází řada rodin do Argentiny (Michalko 1936, 68; Necov 2006, 88), a v roce 1935 odchází z Vojvodova 12 rodin a usazuje se v obci Belinci (Belenci), v oblasti Ludo-

1 Darbistické hnutí založil anglikánský pastor John Nelson Darby $\mathrm{v}$ roce $1830 \mathrm{v}$ Plymouthu. Jeho učení vychází z kalvinismu; darbisté křtí pouze dospělé, kladou důraz na individuální etiku a autoritu Bible a odmítají církevní hierarchii (více $\mathrm{k}$ dané problematice in Jakoubek 2010a: 93, poznámka pod čarou 31).

2 Oni sami a jejich potomci toto označení dnes odmítají a používají označení Křestanské sbory, jejichž součástí se stali po přesídlení do Československa. gorje (Deli Orman) ve východním Bulharsku (Penčev 2006, 95). Bulharská etapa historie „bulharských Čechü“ se uzavírá v letech 1949/1950, kdy naprostá většina $\mathrm{z}$ nich přesídlila do pohraničních oblastí tehdejš́ho Československa, zejména na jižní Moravu (srov. Vaculík 1983).

\section{RODNÉ JMÉNO, JMÉNO PO OTCI A PŘÍJMENÍ U BULHARSKÝCH ČECHŮ}

Rodná jména ${ }^{3}$ dětí vybírali u bulharských Čechů rodiče, většinou ovšem volili v souladu se zavedenými zvyklostmi, které popišseme dále. Dítě nosilo své jméno od narození; obřad křtu, který byl např́ílad v okolní bulharské společnosti tak významný (Krăsteva-Blagoeva 1999, 31-40), zde s aktem pojmenovávání př́mo nesouvisel. Jak jsme viděli, po rozdělení metodistického sboru zhruba polovina vojvodovských domácností děti nekřrtila vůbec, druhá polovina křtila vždy, když se nashromáždil dostatek dětí, často tedy i s několikaměsičním zpožděním. Chybí zde také instituce kmotrovství a s ní související pojetí „duchovního príbuzenstvi', které hrálo v pravoslavných zemích často významnou roli (srov. Bialor 1967 pro Řecko; Hammel 1968 pro Srbsko; Krăsteva-Blagoeva 1999, 40-46 pro Bulharsko). Nejčastěǰ̌́ími mužskými jmény byla jména Josef, Václav, Štěpán, Alois, Karel a Petr, nejčastějšími ženskými jmény Anna, Marie, Olga, Kateřina a Barbora. Jména se dávala většinou po prarodičích, dále pak po strýcích, tetách, a dalších př́buzných, a často se vyskytovala praxe pojmenování prvorozeného po otcových rodičích, druhorozeného po rodičích matčiných (podrobněji k rodným jménům viz Budilová 2012).

Repertoár českých jmen, která se ve Vojvodovu a Belincích dětem dávala, byl značně omezený. Několik nejoblíbenějších jmen se pak statisticky opakovalo častěji než všechna ostatní dohromady. Protože rodiny bulharských Čechů bývaly početné, dostalo se $\mathrm{v}$ každé generaci a $\mathrm{v}$ každé rodině posléze téměř na všechna nejužívanější jména. Nová jména se v Bulharsku téměř nedávala: bulharští Češi si totiž chtěli zachovat svoji odlišnost od bulharského okolí a tak bulharská jména nepoužívali, zároveň však jejich znalost českých jmen byla omezená, proto opakovali stále tatáž. Výjimkou je několik biblických jmen (Ester, Noemi, Samuel), která se objevují v některých rodinách jako jména nová. Řada autorů pritom poukazuje na to, že evangelíci v Evropě i USA často preferovali právě starozákonní jména (Dülmen 1999, 90; Wilson 1998, 193-201). Některé děti své jméno nezdědily po př́buzných ale „narodily se se svým jménem“. Narodilo-li se dítě v některý $\mathrm{z}$ významných dnů (například na Barboru, 4. prosince, či na Štěpána, 26. prosince), bylo pojmenováno jménem, které se s tímto dnem pojilo. Přestože bulharští Češi coby evangelíci neuznávali světce, jejichž jména byla spojována s konkrétními dny v kalendáři, český (církevní) kalendáŕ znali a dodržovali vztah mezi určitými daty a konkrétními jmény (světců). Identický

3 Pro podrobnější nástin problematiky rodných jmen a částečně také př́ímení u bulharských Čechů viz Budilová 2012. 
zvyk (pojmenovávání dětí po významných světcích) převažoval až do konce 19. století také v Bulharsku, od přelomu století však byl stále více nahrazován pojmenováváním po prarodičích (Krăsteva-Blagoeva 1999, 59-61). Mezi nejznámější svátky v bulharském pravoslavném kalendárii, spojované se jménem konkrétního světce, patři například Todorovden, Georgiovden či Dimitrovden (srov. Ognjanova 1999). Zvyk pojmenovávat děti po světcích, na jejichž svátek se narodily, je ovšem doložen také v českých zemích (Doušek 2009, 204-205).

U bulharských Čechů se občas setkáváme také s prostředním jménem, které mělo podobu jména po otci či (u žen) po manželovi. Toto prostřední jméno se objevovalo pouze v oficiálních kontextech, např́klad v dokumentech či na náhrobcích (k vojvodovským náhrobkům srov. Jakoubek 2010a, 177211), naopak v běžném hovoru naši informátoři tato jména nepoužívají vůbec. Uvádějí, že v Bulharsku jméno po otci oni sami mezi sebou nepoužívali, nicméně ve škole a na oficiálních dokumentech se objevovalo, a tak se tímto způsobem při oficiálních př́ležitostech podepisovali. Jméno po otci tedy vzniká jednoznačně pod vlivem bulharštiny a bulharského okolí. V bulharštině se jedná o tzv. baštino ime („jméno po otci“), které bylo oficiální součástí jména každého občana a často (před plným ustavením rodových př́jmení) sloužilo jako příjmení. Dle slov našich informátorů nebylo v některých bulharských rodinách v první polovině 20. století rodové prríjmení ještě ustáleno a tak se místo něj používalo právě baštino ime. U bulharských Češek se na této pozici objevuje jak jméno po otci (u svobodných dívek), tak jméno po manželovi (u vdaných). Toto jméno bývalo vloženo mezi osobní jméno a př́ijmení v nezměněné podobě, bez koncovky - například Anna Karel Krivanek (otec byl Karel Křivánek), případně s bulharskou koncovkou - např́klad Lidia Stefanova Faboukova (manžel se jmenoval Štěpán Fabouk). Jedna z našich informátorek k oficiální podobě svého jména uvádí:

„Já jsem se psala Lidia Josif Krivankova, po otci. Pak Lidia Stefan Faboukova, po manželovi. Někdy jsem se psala jen Lida Josifova, nebo Lida Stefanova. Lída Stefanova mi všichni [Bulhaři] ř́kali. “4

Př́ijmení byla u bulharských Čechů pevně ustálena a předávána $\mathrm{v}$ mužské linii: děti nosily př́ijmení svého otce, vdané ženy př́ijmení manžela. Tento systém nepochybně „zdědili“ po svých předcích, kteří si jej přinesli z habsburské monarchie, kde byla dědičnost a neměnnost příjmení uzákoněna již v roce 1780 (Knappová 1992, 3-9; Moldanová 1983, 12). Vzhledem ke stabilitě manželských svazků pak ve většině př́ípadů platila rovnice jedna rodina, jedno př́imení. Výjimkou byly opakované sňatky a vztahy mezi polovičními sourozenci, kteří mohli být nositeli přímení různých (po svých otcích), nicméně také $\mathrm{v}$ př́ípadě druhého sňatku vdovy s malým dítětem si někdy její nový manžel dítě osvojil a to přijalo jeho př́ijmení. Nejčastějšími př́imeními bulharských Čechů bylo Čížek, Dobiáš, Dvorský, Filip, Hrůza, Karbula, Klepáček, Kňourek, Kopřiva, Kovařík, Křivánek, Pitra, Skalák, Švejda. Jak jsme viděli, bulharští Češi používali k identifikaci jed-

4 Lýdie Fabouková, narozena 1930; Nový Přerov, 19. 1. 2007. notlivců dvoučlenného systému rodného jména a př́ijmení. Repertoár českých rodných jmen byl přitom omezený a také $\mathrm{v}$ důsledku zvyku pojmenovávání dětí po prarodičích se stále reprodukovala tatáž jména. Českých př́ijmení byl také omezený počet, a za dané situace tak nutně a opakovaně docházelo k situacím, kdy řada osob lokálního vesnického společenství nosila stejné jméno i př́ijmení. Tento fakt a potřeba dalšího rozlišování mezi takovými lidmi pak vedl k rozvoji dalšího klasifikačního systému, přezdívek. Obdobná tvorba doplňkových neoficiálních antroponym k rozlišování stejnojmenných osob je popsána $\mathrm{v}$ řadě tradičních lokálních společenství, analyzovanému materiálu je však blízká zejména analogická situace v české vesnici Bígr (Bigăr) v rumunském Banátu (Salzmann 1993).

\section{PŘEZDÍVKY U BULHARSKÝCH ČECHŮ}

Během terénního výzkumu jsme často naráželi na problematiku přezdívek, používaných jak pro celé rodiny, tak pro jednotlivce. Pro identifikaci konkrétních rodin a osob naši informátoři používali přezdívky velmi často, někdy ovšem $\mathrm{z}$ ohledu $\mathrm{k}$ nám a naší předpokládané neznalosti kontextu používali standardního systému křestního jména a př́ijmení. Pokud však hovořili mezi sebou, při odkazování k druhým používali takřka výhradně přezdívek. Explicitně pak uvádějí, že ve Vojvodovu a Belincích se lidé identifikovali spíše přezdívkami než podle oficiálních přímení. $\mathrm{K}$ jednotlivým rodinám ve Vojvodovu se obvykle referovalo prostřednictvím př́imení otce - hlavy rodiny (srov. Budilová 2008, 132). Přirozeným štěpením jednotlivých rodinných domácností pak docházelo $\mathrm{k}$ tomu, že $\mathrm{v}$ obci bylo několik rodin nesoucích stejné př́ijmení, což naši informátoři obvykle reflektují slovy: „Tam bylo Hrůzových (Pitrových, Kňourkových, apod.) několik“, či např́klad „... ale to byli zas jiní Hrưzovi“. K rozlišení těchto jednotlivých rodin pak často sloužily právě přezdívky. Přezdívky používané ve Vojvodovu se dají obecně rozdělit do několika skupin - první je možné označit jako přezdívky patronymické, tedy takové, které vycházely ze jména otce, dědečka či obecně nejstaršího muže v rodině, druhá skupina jsou pak př̀zdívky, které vznikly bud' z určité specifické situace, př́iběhu, či byly odvozeny $z$ vykonávaného řemesla nebo způsobu obživy, a které byly používány obdobným způsobem jako přezdívky patronymické. Oba tyto typy přezdívek se používaly jak pro jednotlivce, tak pro označení celých rodin. Posledním typem přezdívek jsou takové, které označovaly jen jednu konkrétní osobu a na další se nevztahovaly.

Patronymické prezdívky se obvykle odvozovaly od křestního jména otce či dědečka, a tak se např́ílad od jména Ladislav, kterému se obecně říkalo Láda, odvozovala přezdívka Ládovi. Tou se označovala jednak celá rodina, jednak jednotliví rodinní prríslušníci - například dcera tohoto muže byla jmenována jako Kačena Ládová, syn jako Franta Ládů. Podobně se ve Vojvodovu setkáváme s přezdívkami jako Vincencovi, což odkazovalo k variantě jména Václav, Vinca, či s přezdívkou Bedřichovi, odkazující k jménu Bedřich. Objevuje se též pře- 
zdívka Roban (Robanovi) od jména Robert. ${ }^{5}$ Jiná rodina se označovala jako Tondovi, podle křestního jména otce Antonín. Slovy naší informátorky:

„Já jsem si taky vzala Hrůzu, ale to byli zase jiní Hrůzovi. Byli jsme tam Hrůzovi hodně. Jeho táta byl Antonín, tak se jim ř́kalo Tondovi Hrůzovi, nebo jenom Tondovi. “"

Patronymické přezdívky se často používaly $\mathrm{v}$ př́ípadech, kdy vedle sebe žily rodiny stejného př́jmení, které bylo v každodenním životě třeba odlišovat, neboli, jak říkají naši informátoři, pro odlišení jednotlivých větví rodiny. Ve vesnici např́klad vedle sebe bydleli tři bratři - František, Josef a Alois Karbulovi - a protože měli (pochopitelně) všichni stejné příjmení, používaly se pro ně (respektive jejich rodiny) přezdívky Frantíkovi, Josefovi a Lojzovi. V některých př́padech byly rodiny označovány jak přezdívkou odvozenou z rodného jména, tak i skutečným př́ímením, takže se nazývaly např́klad Frantíkovi Karbulovi či Tomšovi Hrůzovi, nebo obrácením pořadí, tedy např́klad Kopřivovi Ládovi. Jindy se však zkráceně používalo pouze přezdívky odvozené $\mathrm{z}$ rodného jména otce, respektive dědečka: Tomšovi, Ládovi, Frantíkovi; př́imení pak bylo jakýmsi zamlčeným předpokladem této identifikace, a tak se $\mathrm{z}$ původně rodného jména (Tomeš) stávala přezdívka (Tomšovi) a $\mathrm{z}$ ní posléze vlastně cosi jako př́ijmení. Takové rodinné přezdívky často přežívaly i do další generace: když se např́klad dospělý syn našeho Františka odstěhoval a založil vlastní rodinu, bylo $\mathrm{k}$ němu a jeho rodině (v některých případech i $\mathrm{k}$ jeho dospělým dětem) i nadále referováno jako k Frantíkovejm.

Patronymické přezdívky byly používány zejména pro děti a v některých př́padech i vnoučata daných osob. Tak mohl být např́klad některý $\mathrm{z}$ obyvatelů Vojvodova znám jako Petr Tomšů, s odkazem k rodnému jménu jeho otce, přičemž příjmení se v tomto označení neobjevovalo vůbec. Všichni mluvčí ovšem příjmení znali a věděli, že v případě Tomšů se jedná o Tomšovy Hrůzovy, a tak je nebylo třeba dodávat (jednalo se tedy vlastně o Petra Tomšů Hrůzů). Dcera nebo vnučka Františka zmíněného $\mathrm{v}$ předchozím odstavci zase mohla být označena např́iklad jako Anka Frantíková, dcera Tomše pak jako Olga Tomšová. Přezdívka zde opět nahrazuje funkci př́jmení. U žen byly používány většinou tyto patronymické přezdivky po otci, at už byly svobodné nebo vdané.

Občas se však objevovala praxe pojmenování vdané ženy prostřednictvím jména jejího manžela (Marjána Tondova, Lída Štěpánova), ovšem tento způsob pojmenování se situačně střídal s jejím pojmenováním prostřednictvím jména otcova. Pokud bylo např́klad v určitém kontextu třeba zdůraznit, z které rodiny nevěsta pochází, použilo se pro ni označení prostřednictvím jména jejího otce. Setkáme se i s identifikací manžela prostřednictvím manželčina jména (Dolfa Káčin,

$5 \mathrm{~V}$ tomto textu čerpám kromě rozhovorů uskutečněných s přesídlenci z Bulharska na dané téma také z materiálu sepsaného panem Miroslavem Štrbkou z Dolních Dunajovic a ze seznamu přezdívek vyhotoveného paní Annou Svobodovou ze Žabčic. Oběma za jejich přispění děkuji.

6 Marie Hrůzová, 1921-2010; Nový Přerov, 10. 8. 2006.
Jirka Rozárčin), které ovšem nebylo tak časté jako kombinace opačná. Označení manželky manželovým jménem je vlastně teknonymem $\mathrm{v}$ Lévi-Straussově smyslu, tedy označením někoho prostř̌ednictvím jeho vztahu k někomu jinému (LéviStrauss 1996, 235). Totožný zpo̊sob pojmenovávání manželek prostřednictvím jmen jejich manželů (nahrazující někdy v každodenním styku plně i př́ijmení) je doložen také v řadě bulharských regionů (Krăsteva-Blagoeva 1999, 116-120). Někteří autoři hovoří v tomto případě o andronymech (Bialor 1967, 105).

Patronymické přezdívky tedy referovaly ke skupině osob („,rodině“, „rodu“) odkazem k jedné osobě, obvykle k nejstaršímu mužskému členovi. Odvozeně pak patronymum sloužilo ke specifikaci jednotlivých konkrétních osob, náležejících do dané rodinné „větve“. Taková přezdívka mohla vzniknout až v určitém okamžiku vývojového cyklu rodiny. Musela být splněna podmínka, že muž, od něhož byla přezdívka odvozena, měl určitý počet potomků, a zároveň museli mít dostatek potomků také jeho bratři, sdílející stejné př́ijmení, takže vznikla potřeba diferencovat mezi jednotlivými rodinnými větvemi. Tohoto bodu bylo pochopitelně dosaženo bud v pokročilém věku dané osoby, nebo až po její smrti. Stát se referentem patronyma tedy bylo možné až ve stáŕí, a nebyla to volba vědomá, byla to situace, $\mathrm{k}$ níž za určitých okolností prostě docházelo. Jména samotného referenta se přitom tato skutečnost nijak nedotkla. Je přitom pravděpodobné, že on sám byl v mládí označován jiným patronymem, odkazujícím např́klad $\mathrm{k}$ jménu jeho děda $\mathrm{z}$ otcovy strany. $\mathrm{V}$ tomto smyslu byla tvorba patronym do určité míry závislá na kontextu a odvíjela se od aktuální situace: např́klad klasifikace a distinkce jednotlivých rodinných „větvi“, která byla nezbytná na Svaté Heleně, se ve Vojvodovu stala zbytečnou, ale byla nahrazena novými klasifikacemi a distinkcemi pramenícími z nové situace (bratři bydlící ve vzájemné blízkosti apod.).

Jiné typy přezdívek, které se používaly stejným způsobem, vznikaly např́klad ze specifického prŕběhu, situace či historky. Mohly bychom je, pro naše účely a pro odlišení od výše uvedených patronymických přezdívek, označovat jako přezdivky situační (tedy: mající původ v určité situaci či příběhu). Tak se naprríklad setkáváme s přezdívkou Banátský, kterou dostala rodina, která se jako poslední v roce 1923 přistěhovala $\mathrm{z}$ Banátu do Vojvodova. Konkrétní osoby pak byly označovány jako Józa Banátský či Francka Banátská, přičemž přijmení samotné je opět vynecháno (všichni ovšem věděli, že se jednalo o Filipovy). Zdrojem další rodinné přezdívky je historka, která se $\mathrm{v}$ různých variantách traduje mezi našimi informátory: Podle jedné $\mathrm{z}$ variant došlo $\mathrm{k}$ hádce mezi manželem a manželkou, a muž, povahy prchlivé, ze vzteku hodil po své ženě sekerou. Okamžitě si však svůj čin uvědomil a zakřičel na svoji ženu: „Káčo, uskoč!“ Tento muž pak začal být označován jako děda Vyskočil nebo Uskoč. Rodina pak vešla ve známost jako Uskočovi, Uskočilovi či Vyskočilovi. Přezdívka se pak také používala víceméně jako př́imení, když byly například děti těchto rodičů označovány jako Vyskočil nebo Vyskočilová. Jiným případem byl vznik přezdívky Svat či Svátu: ta odkazuje k bulharskému př́buzenskému termínu svatove, který je vzájemným 
adresným i referenčním termínem pro rodiče muže a ženy, kteří uzavřeli sňatek. Bulharští Češi sami tento termín nepoužívali, ale znali jeho význam a užití z bulharského kontextu. Jeden $\mathrm{z}$ vojvodovských obyvatel podle jedné varianty příběhu projevoval radost nad tím, že jistá osoba se mu stane „svatem“, př́ipadně si (podle jiné varianty) dělal legraci a danou osobu, která se mu měla stát „svatem“ pořád laškovně oslovoval: „svate, svate!“. Toto jméno mu pak zůstalo a byl označován jako děda Svátu, přičemž přezdívka nadále referovala i k jeho dětem (Anka Svatová) a celé rodině (Svatovi). Jiná rodina byla označována jako Veřrišovi, což odkazuje k příběhu, kdy jeden $\mathrm{z}$ členů rodiny údajně honil po vojvodovských zahradách tele, které mu uteklo, a křričel na něj: „Věříšs, tele, že tě chytnu?“ Takto se pak říkalo i jeho dětem (Venca Věříšu ), kteří však přezdívku vnímali jako pejorativní. Alternativní výklad vzniku této přezdívky pak odkazuje $\mathrm{k}$ výše zmíněnému náboženskému rozkolu v obci, kdy odštěpená část sboru („darbisté“) kladla velký důraz na veřejnou deklaraci své víry, vyznání o vlastním „uvěření. Přezdívka tak má v určitém zlehčujícím tónu - vedle př́běhu o teleti - odkazovat zároveň k této náboženské roztržce. S odkazem na F. Zonabendovou bychom tak mohli říci, že „přezdívka svým vlastním způsobem vyjadřuje to, co sociální cenzura nedovoluje říci přimo" (Zonabend 1977, 271, citace in Krăsteva-Blagoeva 1999, 127).

Jiné přezdívky vznikaly na základě vykonávaného řemesla či jiným způsobem souvisely se zdrojem obživy. Řemeslo se například stalo zdrojem přezdívky pro rodinu pana Dobiáše, který byl krejčí: pro odlišení od jiné větve Dobiášů byli s celou rodinou označováni jako Dobiášovi Krejčíkovi. Podobně pak rodina, jejíž otec byl obecně znám jako Drvodelec (z bulharského "dărvodelec“ = tesař, truhlář) získala přezdívku $D r$ vodelcovi, která se vztahovala také na další členy rodiny. Jiný vojvodovský občan byl označován jako Gerandžija, protože byl specialista na hloubení studní (přezdívka pochází v bulharského "geran“ = studně). Profese mlékaře, který rozvážel mléko do odstředivky (bulharsky "mandra“ = odstředivka, sýrárna) pak zase dala vzniknout přezdívce Mandradžija. Vojvodovský kovář se někdy označoval jako Železár (z bulharského „železar“ = kováŕ, železář) a jeho děti a manželka pak odvozeně jako Železárovy/Železárova. Jedna vojvodovská rodina pak byla označována jako Govedárovi, protože její členové vykonávali pro obec pastvu krav (z bulharského „govedar" = pasák hovězího dobytka). Zdrojem dalších přezdívek používaných ve Vojvodovu byl potom fakt, že v obci byly dva obchody, vlastněné dvěma českými rodinami, které se jmenovaly podle známých bulharských měst „Varna“ a „Šumen“. Tato jména pak byla rozšířena na majitele obchodu a celou jeho rodinu podobným způsobem jako výše zmiňovaná patronyma. Vznik této přezdívky osvětluje naše informátorka: „On tam měl obchůdek a měl nad obchodem vizitku ,Šumen. Tak my jsme jim pak všem ř́kali ,Šumenovi` - Etelka Šumenová, Štéfi Šumenová ... Oni se aj hněvali kluci nejdřív. “7 Zvláštním př́ípadem pak byly přezdívky, které se vztahovaly pouze k jednou konkrétnímu člověku. Většinou se jednalo

7 Barbora Čížková, narozena 1921; Mikulov, 26. 4. 2008. o odkaz $\mathrm{k}$ nějaké vlastnosti dané osoby, či specifickému př́íběhu, který se $\mathrm{k}$ ní vázal. Tak se např́klad jednomu obyvateli Vojvodova říkalo strejček Štěpán hluchej, zatímco jiné obyvatelce obdobně teta Anna hluchá. Druhý př́ípad byl údajně dokonce zdrojem pozdějšího pojmenování pro dům: po přesídlení Čechů a Slováků do Československa si její dům koupil pozdější kronikář obce Necov a, slovy naší informátorky, „... ř́kalo se tam pak, u tety Anny hluchý. Nevím ani, jak se jmenovala, jestli byla Hrůzová, nebo jak. " Jeden z obyvatel Vojvodova byl zase obecně znám jako Doktor Sodov, protože jako dítě vypil u otce $\mathrm{v}$ dílně louh a popálil si hrdlo (poranění spravila až operace po přesídlení do Československa). Jiný (ex-)Vojvodovčan je dodnes znám jako Orator, což vzniklo reflexí jeho řečnických schopností („on tak uměl pěkně vyprávět“).

Někdy má přezdívka původ $\mathrm{v}$ prŕíjmení a nikoli v rodném jménu jako u patronymických prezdívek. Tak tomu je v př́padě jednoho našeho informátora, kterého bylo v každodenních situacích potřeba odlišit od jiného chlapce téhož (rodného) jména. Protože prŕímení tohoto muže je Filip, začalo se mu říkat (a říká se mu dodnes) Filipčo. On sám to popisuje následujícími slovy:

"Já jsem si vždycky hrál s Lojzou Kovaříkem, to byl můj bratranec. Vždycky jsme si hráli u nich na dvoře, a když nás jeho máma volala domu, volala vždycky: ,Lojzo!', ale my jsme nevěděli, kterého Lojzu myslí, tak ona vždycky ř́ká - ,ty ne, ten Filipčó. A to už mi zůstalo. Když se mě ptali, kterej Alois jsem, řekl jsem, že Filipčo. Mě to nemrzí. “9

Zde můžeme společně s Lévi-Straussem konstatovat, že $\mathrm{v}$ tomto př́padě se „...prríjmení stalo jakousi přezdívkou“ (Lévi-Strauss 1996, 230), tedy že se otočil obvyklý vztah příjmení coby prvku klasifikujícího do určité třídy a jména jako jednotky, která rozlišuje konkrétní individuum: př́ijmení zde bylo použito pro identifikaci konkrétního jednotlivce $\mathrm{v}$ rámci širší třídy „Aloisü“. Podobným případem přezdívky odvozené $\mathrm{z}$ př́ijmení je Josef Hrůza, žijící v Novém Přerově, který je všemi označován jako Hrůzinek. Podobně se sestrám Pitrovým zase někdy ř́kalo Pitrinky.

Vrátíme-li se ještě k Filipčovi, ukáže se jedna zajímavá a důležitá věc. Pan Filip byl (a dodnes je) jako Filipčo znám mezi Čechy (a Slováky) z Vojvodova a Belinců. Ve Vojvodovu ovšem kromě Čechů a Slováků žili také Bulhaři, a ti téhož člověka označovali svojí vlastní přezdívkou, a to jako Belija (z bulharského „bílýc “) ${ }^{10}$, pro velmi světlou barvu jeho vlasů. Tento př́pad odkrývá fakt, že někteří obyvatelé Vojvodova měli přezdívky dvě: jednu, která vznikla a byla používána $\mathrm{v}$ české protestantské komunitě a druhou, kterou vytvořili a používali místní Bulhaři. Přestože Češi bulharské přezdívky znali, nikdy je nepoužívali, a naopak. $\mathrm{V}$ rámci jedné vesnice se tak setkáme se dvěma vzájemně uzavřenými komunitami

\footnotetext{
8 Barbora Čížková, narozena 1921; Mikulov, 26. 4. 2008.

9 Alois Filip, narozen 1919; Valtice, 13. 6. 2009.
}

10 Informaci čerpám $\mathrm{z}$ písemného záznamu vlastního životopisu vojvodovského Bulhara, T. Metodieva Stančeva (1920-2011), sepsaného dne 15. 6. 2007 a uloženého v archivu M. Jakoubka, kde čeká na publikaci. 
lidí, přičemž právě používání přezdívek odhaluje hranice mezi nimi.

Původ některých přezdívek je dnes už nezjistitelný; můžeme-li však usuzovat $z$ prŕípadu poměrně nedávného (po přesídlení), kdy se jistému muži ř́ká „Havel“ pouze proto, že se setkal s Václavem Havlem a potřásl si s ním rukou, lze předpokládat, že jejich původ mohl být velmi rozmanitý. Během terénního výzkumu jsme se tak setkávali i s přezdívkami, jejichž význam a původ už nikdo neznal (nebo nechtěl znát). Např́iklad místnímu kováři, Alosi Pitrovi, se říkalo Beňa, a jeho rodině $B e-$ ňovi, ovšem původ této přezdívky neznáme. Kuriózní je pak např́íklad způsob referování $\mathrm{k}$ jedné rodině jako $\mathrm{k}$ Duparinovým, což je podle některých informátorů možná odvozeno z bulharského "dupe“ = zadek (tato interpretace je však nejistá). Dalšími přezdívkami neznámého původu jsou např́iklad Čacharanda či Hatko.

Zcela specifický prrípad přezdívek pochází z Belinců, obce ve východním Bulharsku, kde Češi žili od roku 1935 společně s Turky. Turečtina byla také zdrojem přezdívek dvou mužů stejného jména. Karlu Pitrovi Turci ŕíkali Kjučuk Karlo, aby jej odlišili od Karla Kňourka, kterého nazývali Kodžaman Karlo. Původ přezdívek byl v tělesném vzrůstu obou Karlů - „Kodžaman“ pochází z tureckého „kocaman“ (= velký), „Kjučuk“ zase $\mathrm{z}$ tureckého „küçük“ (= malý). Tyto přezdívky byly používány místními Turky, spadají tedy do stejné kategorie jako výše zmíněná přezdívka Belija, kterou by snad bylo možné nazvat exo-přezdívky (tedy takové, které byly používány ne-členy daného společenství). Tyto přezdívky se do určité míry - nicméně spíše v poloze žertovné - ujaly také mezi bulharskými Čechy.

\section{POUŽÍVÁNÍ A VÝZNAM PŘEZDÍVEK}

Tvorbu přezdívek u bulharských Čechů je možné sledovat z perspektivy vývoje českých osobních jmen, protože řada z nich, zejména patronymické přezdívky, byla odvozována z českých rodných jmen (Tomšovi, Ládovi), jiná pak zase z českých př́ímení (Filipčo, Pitrinky, Hrůzinek). Další typ přezdívek, jejichž původ je ve specifické situaci či prŕběhu, je zase vytvořen z českých sloves (Věrí̌s, Uskoč). Stejně tak je možné pozorovat vliv bulharského okolí na tvorbu přezdívek bulharských Čechů: tento vliv je zřejmý zejména u přezdívek vzniklých z vykonávaného řemesla (Gerandžija, Drvodelec) či odkazujících (př̀neseně) na bulharské reálie (Varna, Šumen). Ve dvou případech je pak zaznamenán ve tvorbě přezdívek také vliv turečtiny (Kjučuk Karel a Kodžaman Karel).

Tvorba přezdívek je přitom $\mathrm{v}$ česky mluvícím prostředí poměrně dobře doložena už od nejstarších období, jako příklad nedědičného pojmenovávání osob, které bylo používáno zpravidla v nepř́tomnosti označovaného a odkazovalo většinou na nějakou „nápadnost nebo neobvyklost v podobě, povaze, na vadu, činnost, oděv, majetek, na nějakou př́hodu, apod.“ (Beneš 1962, 8). Také v českých osadách v rumunském Banátu je popsán systém přezdívek sloužících k rozlišení stejnojmenných osob a používaných často pouze $\mathrm{v}$ neprrítomnosti jejich nositelů (Utěšený 1964, 210-211; Salzmann 1993, 150-154). V bulharské společnosti (Krăsteva-Blagoeva 1999, 126-132) je doloženo použínání přezdívek, které měly jak individualizační význam, odkazovaly k charakteristickým rysům jednotlivce a jejich smyslem bylo odlišovat stejnojmenné $\mathrm{v}$ rámci lokálního společenství, tak povahu klasifikační: tím, že se předávaly z generace na generaci, odkazovaly ke kategorii lidí. Protože v Bulharsku nebyla do konce 19. století oficiálně ustanovena rodinná př́imení, přezdívky se postupně přeměňují právě na dědičná př́ijmení (Krăsteva-Blagoeva 1999, 127).

Bulharští Češi používali výše načrtnutý systém přezdívek jako klasifikační systém, který měl zjednodušit orientaci mezi stejnojmennými osobami a rodinami. Přezdívky se však používaly výhradně jako termíny referenční, nikoli adresné. Jako adresné termíny sloužily mezi př́buznými bud' prŕbuzenské termíny (maminko, tatínku, dědečku, strýčku) doprovázené vykáním, obraceli-li se členové mladší generace ke starším (a to i v prrípadě vlastních rodičů), nebo osobní jména, jednalo-li se o styk mezi sobě rovnými, tedy osobami ze stejné generace, nebo o oslovení mladších staršími. Nepříbuzní, obracel-li se mladší na staršího, používali ke vzájemnému oslovování také prríbuzenských termínů (teto, strejčku), v tomto případě používaných v metaforickém smyslu, a vykání. Ve stejné generaci a v oslovení mladších staršími se pak používala bud' rodná jména (Barči, Štéfi, Lojzo), nebo oslovení bratře, sestro, v kontextu společných náboženských shromáždění. Došlo-li však $\mathrm{k}$ posunu $\mathrm{v}$ generacích např́klad tak, že jedna ze dvou osob ve vzájemné genealogické pozici (v nativní dikci) první sestřenice, byla, řekněme, o patnáct let starší než druhá, pak mladší starší vykala a oslovovala ji teto. $Z$ toho je zřejmé, že při volbě odpovídajícího oslovení nebyla rozhodující genealogická pozice, ale spíše (relativní) věk dotyčných. Pokud jde o termíny referenční, byla zase podle totožných kritérií používána bud' rodná jména (Barči, Tonda), hovořilo-li se o vrstevnících nebo hovořil-li starší o mladším, doplněná prrípadně o příjmení (Tonda Kovaříků). Pokud mluvil mladší o starším nebo cizím člověku, používal obvykle zase termíny strejček/ teta/děda, často doplněné bud' o rodné jméno (strejček Franta), pokud šlo o příbuzného, či o př́imení (strejček Kovařík), pokud šlo o cizího. $\mathrm{V}$ takových případech se pak často používaly také přezdívky (strejček Drvodelec, teta Kačena Ládová, teta Anka Svátová).

Jak bylo naznačeno výše, řada přezdívek byla dotyčnými vnímána jako pejorativní nebo přinejmenším neupřednostňovaná forma označení. $Z$ tohoto důvodu se přezdívky nikdy nepoužívaly $\mathrm{v}$ přímém oslovení, ale vždy pouze jako termíny referenční. Podobný způsob používání přezdívek je doložen také v řadě jiných společností, v nichž jsou přezdívky, odkazující k nějaké osobité charakteristice jednotlivce, také používány pouze jako termíny referenční a nikdy ne jako a termíny adresné (Wilson 1998, 283). Také v Bulharsku se přezdívky zpravidla nepoužívaly při oslovení a některé se dokonce před dotyčnými tajily, právě pro jejich negativní význam; ze stejného důvodu pak lidé takto označení často vymýšleli alternativní vysvětlení pro vznik dané přezdívky, který je stavěl do lepšího světla (Krăsteva-Blagoeva 1999, 128). 
Jak jsme viděli, přezdívky se většinou dědily, kromě několika málo výjimek, jež platily pouze pro konkrétní jednotlivce (Filipčo, Orator, Doktor Sodov). Tyto pro jednotlivce specifické přezdívky nikdy nedostávaly ženy: ženy se tedy mohly stát nositelkami přezdívek pouze tak, že je zdědily (pro podobnou situaci v Řecku srov. Bialor 1967, 104-105), př́ípadně dostaly po manželovi. Patronymické přezdivky, a přezdívky odvozené od řemesel, které se dědily (Anka Frantíková, Tonda Krejčíků), pak naznačovaly prŕslušnost jednotlivce $\mathrm{k}$ nějaké kategorii lidí, měly tedy klasifikační význam. Patronymické přezdívky často sdíleli lidé, kteří mohli být nositeli různých přímení, tyto přezdívky se totiž (narozdíl od př́jmení) předávaly bilaterálně: tak mohla být například Anka Frantíková ve skutečnosti př́ijmením, řekněme, Dobiášová, přestože přezdívka Frantíkovi se obecně pojila s prŕjmením Karbulovi.

V systému pojmenovávání i oslovování se odráželo několik prvků hodnotového systému bulharských Čechů. Důraz na hierarchii mezi generacemi se odrážel ve vykání dětem rodičům a všem dospělým osobám, stejně jako v používání zdvořilého oslovení strejčku, teto. Protichůdný, ale též přítomný důraz na rovnost před Bohem, který se manifestoval zejména ve shromáždění, kde vedle sebe, slovy jednoho našeho informátora, „... seděli $v$ jedné lavici chudý $i$ bohatý ${ }^{\prime 11}$, se zase projevoval $\mathrm{v}$ používání příbuzenských termínů (bratře, sestro) mezi sobě rovnými (dospělými) v církvi. Převažující pocit společenství pak zase odráží používání příbuzenských termínů (strejčku, teto), pro všechny dospělé osoby.

Skutečnost, že ve společenství bulharských Čechů (které se dlouho chápalo především jako společenství věřících) se používal systém přezdívek pro jednotlivce i rodiny, který jejich bulharské okolí sice znalo, ale nepoužívalo, a že Bulhaři ve Vojvodovu a Turci v Belincích zase měli (dokonce i pro stejné osoby) alternativní systém přezdívek, zase poukazuje na hranice mezi komunitami, které žily společně v jedné obci a přicházeli do každodenního kontaktu, přesto se však vnímaly a vymezovaly jako společenství odlišná (pro přezdívky jako marker skupinových hranic srov. Wilson 1998, 281-283).

\section{LITERATURA}

Barnes, James A. (1967): Genealogies. In: Epstein, Arnold L., ed., The Craft of Social Anthropology, London: Tavistock Publications, 101-127.

Beneš, Josef (1962): O českých př́ijmeních. Praha: Nakladatelství Československé akademie věd.

Bialor, Perry A. (1967): What's in a name? Aspects of the social organization of a Greek farming community related to naming customs. In: Lockwood, William G., ed., Essays in Balkan Ethnology, Berkeley: The Kroeber Anthropological Society Papers, 95-107.

Botík, Ján (2005): Česi a Slováci v bulharskom Vojvodove. In: Ročenka Spolku Slovákov z Bulharska, Bratislava: Spolok Slovákov z Bulharska, 33-38.

Bruck, Gabriele vom - Bodenhorn, Barbara (2006): "Entangled in histories": An Introduction to the Anthropology of Names and Naming. In: Bruck, Gabriele vom - Bodenhorn, Barbara, eds., The Anthropology of Names and Naming, Cambridge University Press, 1-30.

Budilová, Lenka (2008): Některé aspekty př́ibuzenství a sňatkových vzorců u 'vojvodovských Čechů'. Českýlid/Etnologický časopis, 95 (2), 127-142.

11 Petr Klepáček, narozen 1943; Velké Př́lepy, 18. 10. 2011.
Budilová, Lenka J. (2011): Dědické strategie a předávání gruntu ve vztahu k prríbuzenství a genderu. Př́ípad bulharských Čechů, 1900-1950. Historická demografie 35/2011, 187-218.

Budilová, Lenka J. (2012): „Ajt̄ se neztratí jméno“. Jména a pojmenovávání u bulharských Čechů. Český lid/Etnologický časopis (v tisku).

Doušek, Roman (2009): Sebranice a jejich rychtáŕ Ondřej Kanýz (1694-1761). Vesnická komunita a její kultura v první polovinè 18. století. Brno: Masarykova univerzita.

Dülmen, Richard van (1999): Kultura a každodenní život v raném novověku (16.-18. století). I. Dưm a jeho lidé. Praha: Argo.

Geertz, Hildred - Geertz, Clifford (1964): Teknonymy in Bali: Parenthood, Age-grading and Genealogical Amnesia. Journal of the Royal Anthropological Institute, 94, 94-108.

Goodenough, Ward H. (1965): Personal Names and Modes of Address in Two Oceanic Societies. In: Spiro, Melford E., ed., Context and Meaning in Cultural Anthropology, New York: The Free Press, 265-276.

Hammel, Eugen A. (1968): Alternative Social Structures and Ritual Relations in the Balkans. New Jersey: Prentice-Hall, Inc., Englewood Cliffs.

Jakoubek, Marek (2010a): Vojvodovo - etnologie krajanské obce v Bulharsku. Brno: CDK.

Jakoubek, Marek (2010b): From believers to compatriots: the case of Vojvodovo, a 'Czech' village in Bulgaria. Nations and Nationalism 16 (4), 675-695.

Knappová, Miloslava (1989): Rodné jméno v jazyce a společnosti. Praha: Academia.

Knappová, Miloslava (1992): Příjmení v současné češtině. Jazyková příručka. Liberec: AZ KORT, a.s.

Knappová, Miloslava (1999): Přezdívky v proměnách staletí. Acta onomastica 40, 82-88.

Krăsteva-Blagoeva, Evgenia (1999): Ličnoto ime v bălgarskata tradicia. Sofia: Akademično izdatelstvo „Prof. Marin Drinov“.

Lévi-Strauss, Claude (1996 [1962]): Myšlení př́rodních národů. Praha: Dauphin.

Michalko, Ján (1936): Naši v Bulharsku. Pädesiat rokov ich života, práce, piesne a zvykov. Myjava: Knihtlačiareň Daniela Panického.

Moldanová, Dobrava (1983): Naše př́imení. Praha: Mladá Fronta.

Necov, Neco P. (2006): Dějiny Vojvodova. In: Jakoubek, Marek - Nešpor, Zdeněk - Hirt, Tomáś, eds., Neco Necov Petkov: Dějiny Vojvodova. Vesnice Čechů a Slováků v Bulharsku, Plzeň: Občanské sdružení Vojvodovo, 27-89.

Nešpor, Zdeněk R. - Hornofová, Martina - Jakoubek, Marek (2001): Čeští nekatolíci v rumunském Banátu a v Bulharsku. Část třetí. Vojvodovo, obec denominačního typu. Lidé města, 5, 62-86.

Ognjanova, Elena (1999): Ot koleda do koleda. Sofia: „Koralov u sie“.

Penčev, Vladimir (2006): Tempus edax rerum aneb o minulosti a současnosti vojvodovských Čechů. In: Jakoubek, Marek - Nešpor, Zdeněk - Hirt, Tomáš, eds., Neco Necov Petkov: Dějiny Vojvodova. Vesnice Čechů a Slováků $v$ Bulharsku, Plzeň: Občanské sdružení Vojvodovo, 90-105.

Pine, Frances (1996): Naming the house and naming the land: Kinship and social groups in Highland Poland. The Journal of the Royal Anthropological Institute, 2, 443-59.

Pleskalová, Jana (1998): Tvoření nejstarších českých osobních jmen. Brno: Masarykova univerzita $v$ Brně.

Pleskalová, Jana - Karlík, Petr - Nekula, Marek, eds. (2002): Encyklopedický slovník češtiny. Praha: Nakladatelství Lidové noviny.

Rivers, William Halse R. (1900): A Genealogical Method of Collecting Social and Vital Statistics. The Journal of the Anthropological Institute of Great Britain and Ireland, 30, 1900, 74-82.

Salzmann, Zdeněk (1993): Přezdívky v Bigăru: prríspěvek k antroponymii česky mluvící vesnice $\mathrm{v}$ jihorumunském Banátu, Naše řeč, roč. 76, č. 3 (1993), 146-156.

Svoboda, Jan (1947): Slovanská osobní jména ve světle národopisu. Slavia. Časopis pro slovanskou filologii 18, 1-2, 107-110.

Svoboda, Jan (1964): Staročeská osobní jména a naše př́imení. Praha: Nakladatelství československé akademie věd.

Šmilauer, Vladimír (1974): Úvodem, In: Kopečný, František, Prưvodce našimi jmény. Praha: Academia, 9-29.

Utěšený, Slavomír (1964): Vlastní jména osob a zvířat u Čechů na jihu rumunského Banátu, Naše řeč 47, 1964, 208-216. 
Vaculík, Jaroslav (1983): Bulharští Češi a jejich reemigrace v letech 19491950. Českýlid, 70 (4), 82-85.

Wilson, Stephen (1998): The means of naming. A social and cultural history of personal naming in western Europe. London and New York: Routledge.

Zonabend, Françoise (1977): Pourquoi nommer? Les noms de personnes dans une village Francoise: Minoten-Chatillonnais. In: L'Identitè, Seminaire interdisciplinaire dirige par Claude Lévi-Strauss, professeur au College de France, 1974-1975, Paris: Grasset, 257-279.

\section{AUTORKA}

Budilová, Lenka (4. 4. 1980, Rokycany), antropoložka a etnoložka. Žije v Rudné u Prahy s Markem Jakoubkem a krom péče o dceru Barboru se věnuje také antropologickým tématům jako je teorie příbuzenství či problematika terénního výzkumu. V roce 2010 obhájila disertační práci na téma Vojvodovo, česká vesnice v Bulharsku (Pří- buzenství, manželství a dům) na Katedře antropologických a historických věd Fakulty filozofické Západočeské univerzity v Plzni, kde od roku 2006 přednáší spřízněná témata. V současné době se zabývá zejména otázkami dědické praxe, sňatkových strategií a migračních pohybů obyvatel bulharských obcí Vojvodovo a Belinci.

Vedle problematiky bulharských Čechů se společně s Markem Jakoubkem výzkumně, publikačně i překladatelsky řadu let věnovala tématu cikánských/romských skupin v České a Slovenské republice (Budilová, Lenka - Jakoubek, Marek, eds. 2007: Cikánská rodina a př́buzenství. Plzeň: Západočeská univerzita v Plzni a Vlasta Králová; Jakoubek, Marek - Budilová, Lenka, eds. 2009: Cikánské skupiny a jejich sociální organizace. Brno: Centrum pro studium demokracie a kultury).

Kontakt: Mgr. Lenka J. Budilová, Ph.D., Katedra antropologických a historických věd Fakulty filozofické Západočeské univerzity v Plzni, Tylova 18, 30614 Plzeň, e-mail: budlenka@hotmail.com. 